\title{
CHANGE MUST COME FROM BELOW BUT ALSO FROM THE TOP': STRATEGIES FOR ROMA SCHOOL DESEGREGATION IN THE CZECH REPUBLIC
}

\section{Zbyněk Němec ${ }^{1}$}

${ }^{1}$ Faculty of Education, Charles University, Prague, Czech Republic

\author{
Eduport 5 (1) - Reviewed Papers \\ DOI: 10.21062/edp.2021.005
}

\begin{abstract}
Roma children represent a discriminated minority in education in many European countries. Educational research shows that Roma students attending segregated schools have low educational achievement, but the strategies for reversing segregation - which have already been successfully used by some schools in practice have not yet been sufficiently described.

The article draws on qualitative research into Roma students' segregation in Czech elementary schools, aiming to identify good practice leading to desegregation.

The interviews were conducted with six educational experts and with teaching staff from eight elementary schools, whether segregated or successfully dealing with the risk of segregation. The data was processed via thematic analysis.

The results indicate two main areas of intervention: 1) supporting the transition of Roma students to nonsegregated mainstream schools via changing catchment areas, "bussing" and even closure of segregated schools; 2) making segregated schools more attractive to non-Roma parents and children via introducing alternatives into educational programs, increasing cooperation with out-of-school partners and improving the schools' reputation.

In conclusion, desegregation is achievable with the cooperation of all relevant actors. The remaining challenge for the future is to change the discourse - from a narrow view of Roma desegregation to the wider idea of inclusive education for all.
\end{abstract}

Keywords: school segregation, discrimination, desegregation

\section{INTRODUCTION: SEGREGATION OF ROMA STUDENTS IN EDUCATION}

The right to access education without any discrimination is one of the basic pillars of inclusive education. Report by Council of Europe $(2017$, p. 17) states that: “...states must take measures to ensure that economic, social, cultural or personal circumstances do not turn into sources of discrimination preventing some children from benefitting from a satisfactory learning experience on an equal footing with others. "In order to do so, as the report itself reminds, it is necessary to ensure quality of education in all schools, raise awareness of inclusive education, plan education supply "with an inclusive lens" (p. 22) and, as regards the education of students from ethnic minorities, also to adopt a desegregation strategy.

School segregation of ethnic minorities and socially disadvantaged students is nowadays one of the main issues in contemporary education in central and eastern Europe. Although the numbers of Roma children being educated in segregated educational settings vary in different EU member states, in many cases the numbers are alarming - in countries like the Czech Republic, Spain or Romania approximately 30\% of Roma students attend all-Roma schools or at least schools in which Roma students are highly over-represented. Even worse is the situation in Bulgaria, Slovakia and Hungary, where over a half of all Roma children attend segregated schools (European Union Fundamental Rights Agency, 2017). 
Segregation itself is conceptualized simply as the physical separation of Roma students from their non-Roma peers (Rostas, Kostka, 2014) or as a situation in which Roma students are educated in schools or classes separately from their non-Roma peers in numbers that significantly exceed their proportional representation in the whole population or area, with limited opportunities for mutual interaction and with different educational opportunities (Public Defender of Rights, 2018).

Within the mainstream educational system, the main visible form of segregation is based on the existence of all-Roma schools or at least schools in which Roma students represent a majority of their school population (Council of Europe, 2017); this form of inter-school segregation is often caused by the residential segregation of the Roma minority in socially excluded areas and is usually connected with the phenomenon of 'white-flight' a process in which non-Roma parents move their children to other schools with a lower percentage of Roma students (Arabadjieva, 2016; Araújo, 2016). In the Czech Republic, the Roma students represent less than $4 \%$ of the total number of students in elementary education, but there are 83 schools in which the number of Roma students outweighs the number of non-Roma students, and 12 of these schools are attended only by Roma (MEYS, 2017).

An alternative form of separation in the mainstream educational system is called 'intra-school' or also 'classroom' segregation. In this type of segregation, Roma students attend ethnically mixed schools, in which they are separated in all-Roma classes, although the reason given for separating them is not their ethnicity the other, non-Roma classes are simply labelled 'linguistic' or 'mathematical' and presented as classes for talented students (European Roma Rights Center, 2004). In some cases, these separated Roma classes are established under pressure from non-Roma parents in order to prevent the withdrawal of majority students and their removal to other, less-Roma schools (Messing, 2017). In the Czech Republic, intra-school segregation is evidenced, but the extent is unclear (Public Defender of Rights, 2018).

In some cases, segregation can result from Roma students' over-representation in special schools, which mainly serve children with mild intellectual and other developmental disabilities (European Roma Rights Center, 2004). In the Czech Republic high numbers of Roma children are being misdiagnosed with special educational needs (Cahsman, 2016). One of the main instruments used for recognizing this type of segregation is a 'composition index' which compares representation of different ethnic groups in the mainstream educational environment and their representation in special educational programs (Harry, 2007) - according to the data given by the composition index, there is high over-representation of Roma students in special schools in many European countries. In the Czech Republic, where less than $4 \%$ of students in mainstream elementary education are Roma, in education programs designed for students with mild intellectual disabilities Roma represent $29 \%$ of this student population (Committee of Ministers, Council of Europe, 2019).

The phenomenon of Roma segregation has many serious consequences, not only in educational, but also in social and economic aspects of life. The quality of the educational process and its outcomes in a segregated school is, compared to mainstream schools, significantly lower. Segregated schools attended predominantly by disadvantaged students require more human, financial and advisory resources, as well as the strong leadership of its headteachers, and 'in the absence of such means, educational levels usually drop' (Council of Europe, 2017 , p. 11). Because of the lower quality of education, many segregated school leavers are less likely to attend good high schools and as adults many of them remain unemployed and dependent on welfare benefits. Segregated schooling clearly reinforces the social exclusion of socially disadvantaged Roma minorities (Public Defender of Rights, 2018).

Although segregation of Roma students in education is a proven phenomenon, only a little is known about the possible solutions to this problem. Researchers point to dysfunctional governmental strategies that contain little or no suggestions for concrete steps towards desegregation (Arabadjieva, 2016) and mention namely the Czech Republic and Slovakia, where desegregation plans 'did not come equipped with any concrete policy tools which could facilitate their implementation.' (Rostas, Kostka, 2014, p. 277). Therefore, the research described in this article focused on practical strategies for desegregation and tried to answer the question of how to address the segregation of Roma elementary school students in practice.

\section{METHODOLOGY}

The article draws on a larger qualitative research project, which was realized during 2019 and focused on many different aspects of Roma students' segregation in Czech schools (Němec, 2020). The issue of segregation was 
examined through qualitative research, which was once described as being close to detective work (Hendl, 2008) - in this research, segregation would be 'the crime', educational staff and experts would be 'the main witnesses' and their statements 'the main evidence'.

Eight elementary schools were involved in the research; the names of the schools have been changed to protect their anonymity. Schools were chosen intentionally because of their different experiences with the issue: The first one, Linden Tree Elementary, is situated in a socially excluded area and attended only by Roma. Three other schools attended predominantly by Roma - Beech Tree Elementary, Poplar Tree Elementary and Oak Tree Elementary - are situated in urban areas of larger cities and their segregation status is not a consequence of segregation in housing but results from the prejudice and educational preferences of local communities. A similar situation also exists in Chestnut Tree Elementary, where Roma students comprise only about one third of the school population, but in the neighborhood the school is still known as the 'Roma school'. On the other hand, three participating 'non-segregated' schools, Pine Tree Elementary, Fir Tree Elementary and Spruce Tree Elementary, were invited to participate in the research as examples of 'good practice', because of their previous experience of stopping or preventing the process of becoming segregated.

The preparatory phase of the project worked with documents' analysis, mainly in order to prepare the startingpoints for the subsequent interviews with selected experts and pedagogical staff. Annual school reports, reports by the Czech School Inspectorate, and school educational programs, as well as previous interviews with experts published in various media were analyzed.

The main phase of the data creation was realized through semi-structured interviews. One interviewed group consisted of six experts who were addressed due to their many years of experience with the issue; the experts were from governmental as well as nongovernmental organizations, three of them are themselves Roma. The second group surveyed was made up of pedagogical staff from eight elementary schools - in each school separate interviews were carried out with the principal and with one other teacher who was experienced in educating Roma children. In schools, the interviews were conducted in the offices of the participants. In the group of experts, the interviews were conducted in their offices or at the office of the researcher. All the participants were acquainted with the anonymity of data processing and gave their informed consent to participation in the research. The average length of one interview was one hour and one minute, the shortest interview took forty-one minutes, the longest interview lasted ninety-seven minutes. All interviews were audiorecorded and transcribed into written form. Following the interviews and their initial analysis, all participants received several additional questions via e-mail.

Finally, the data were processed via thematic analysis inspired by selected strategies of grounded theory (Strauss, Corbin, 1999). In analysis, seven different categories filled with one hundred and fifty-five different codes were created. The following text describes the main findings from the category focused on strategies for desegregation and tries to answer the question of what examples of good practice can be found that could solve or at least minimize the extent of the segregation of Roma students in elementary schools.

\section{RESULTS}

Among all the desegregation strategies mentioned by the research participants, most often discussed was the possibility of transferring Roma students to other, non-segregated, mainstream elementary schools. Such a process could be enhanced by the closure of segregated schools, changes in the schools' catchment areas in order to distribute Roma children to different schools and "bussing" some Roma students to non-segregated schools. To make this process successful, collaboration between schools and municipalities, as well as changes in Roma parents' attitudes and in the atmosphere of non-segregated schools, seem to be the vital conditions.

\section{A. Supporting the transition of Roma students to non-segregated schools.}

The first and strictest possible intervention that could lead to an increase in the attendance of Roma children at non-segregated elementary schools, is the gradual closure of segregated schools. Although such school closures are difficult to imagine in many localities, in selected cases involving smaller schools with fewer students, it could be part of optimizing the entire school network.

Vojtěch, an expert: 'I agree that the Czech School Inspectorate, the Ministry of the Interior and the Ministry of Education should intervene in cases of segregation, although recipes for solutions are likely to vary from 
situation to situation and require long-term efforts. However, good practice of closing segregated schools - in cities like Sokolov or Krnov - is already known in the Czech Republic.'

One of the schools involved in the research, Spruce Tree Elementary, has in the past received a few Roma students from a canceled segregated special school and developed strategies to successfully include these students. The example of this school shows that the admission of Roma students, even when they are students with intellectual disabilities as in this case, from an abolished segregated school may not be perceived by ordinary school teachers as unacceptable, especially when it involves a smaller number of students from the local community.

Tomáš, principal, Spruce Tree Elementary School (4\% socially disadvantaged Roma students): 'I think that the Roma students were accepted, as I say, very humanely. With a lot of understanding. Not by everyone, but I felt it was good. Because they were local. And when you had played, figuratively speaking, with someone in the sandpit and he later gets into trouble, then it is hard to say no. And the people here know each other, more or less.'

Another idea discussed as a possible measure to achieve de-segregation was so-called "bussing" - organizing the local bus transport in order to facilitate the physical accessibility of non-segregated schools for Roma children living in socially excluded areas. However, this seems to be limited by the low level of willingness of Roma parents to let their children commute.

Kateřina, principal, Linden Tree Elementary School (100\% socially disadvantaged Roma students): 'So, a few years ago I tried to get small children from the second grade to [name of the local city]. I always did this with the agreement of their parents, I chose a family that is decent and I knew they would help those children. The children, if they went to the [name of the local city] school, the pressure on them would be great, and it was necessary to have someone to help them. So I found principals who would take two, three children to [name of the local city], but then it fell apart because of the parents. They didn't want the commute. Then when they move to [name of the local city] for housing, they put the children there. But I still think our school is not quite right here, given that only Roma children are here. That they really need to see something else.'

In many cases, the municipalities and their cooperation with local schools play a key role in the effort to include Roma students in a non-segregated school environment. The main instrument held by municipalities is the setting of the school catchment areas, which can divide the population of excluded Roma areas into a few different schools or - in the worst case - could send the whole population of the excluded Roma areas to one segregated school. And there already exist examples of good practice, in which the long-term responsible approach of a municipality to setting the school catchment areas has significantly influenced the process of admitting Roma students to non-segregated schools.

Alžběta, teacher, Pine Tree Elementary School (17\% socially disadvantaged Roma students): '... But I have to say that to us some of the problematic districts have disappeared. Because there are principals and schools which just don't want Roma children, and they just tell them that they will not take them. And that they are full. And now they can't say no to them because they are in their catchment area. Before that, most of the kids came to us, but now they have to be there.'

For some segregated schools, their status is further strengthened by the above-standard offer of services for socially disadvantaged Roma students - these schools offer more support in the form of teaching assistants, tutoring, preparatory classes, etc. Other schools, which do not have these above-standard services, then refer socially disadvantaged Roma students to a segregated school, justifying it through citing the higher level of support services offered at the segregated school. In order to encourage Roma students to attend nonsegregated schools, it is desirable that municipalities, in cooperation with local schools, create a system of support services available at all schools in the region. For example, ESF-funded projects can be used to implement such a widely available support system.

Iva, principal, Pine Tree Elementary School (17\% socially disadvantaged Roma students): 'The municipality, its Development Department, organized the 'Inclusion in Schools' project and is now implementing the 'School for All' project. The projects are for all schools in the city and create resources to finance employees who support inclusive education. In the current project, our school has employed an educational consultant as an inclusion coordinator and also a career consultant. The career counselor, who is responsible for career choices and all 
related matters, works with the children from the 5th grade and has enough time to work with families where education is not a priority. The Inclusion Coordinator takes care of all the students with SEN and manages the entire School Counseling Center, which currently involves twenty-three teaching staff-eighteen assistants, two special teachers, a school psychologist, a career counselor and a school prevention counselor.'

Some barriers to the inclusion of Roma students in mainstream schools may also be linked to Roma parents' distrust of the education system and their lower ability to orientate in it. Therefore, cooperation with Roma parents, increasing their awareness of the importance of education as well as their knowledge of the education system, may be another important means of supporting the inclusion of Roma students in non-segregated schools. A number of examples show that cooperation with local NGOs can be very beneficial in this area.

Petra, an expert: '... I believe that the change must come from below but also from the top. That it is never only one group or only one thing that has to be done to change something. It is always the interplay of the relevant actors. So the feeling, the change, I see in our region, is that by organizing the community we have empowered Roma parents, so they really know what their duty is, defend their rights, know how to act... and the mentality or ways of thinking of those Roma parents are changing. So it's not the argument any more, that I'll put my child among his peers that he knows well and where he is safe. No, the parent sends the child to a nonsegregated school and thinks it's good and stands up for it.'

Another obstacle to the attendance of Roma students at mainstream elementary schools is prejudice, which occurs not only among the other students but among the teachers as well. This prejudice means that the Roma student does not feel comfortable in the mainstream school and sometimes even leads to the bullying of the child. And so, in order to facilitate the attendance of Roma students, it is necessary to change the atmosphere in non-segregated schools. Like any other child, a Roma child needs to attend a school where he/she feels safe and fully accepted.

Petra, an expert: 'There are more obstacles, sometimes the underestimation of the child by the teacher, which may even be perceived as bullying. Sometimes the teacher does it covertly, destroying the self-confidence of the child. The Roma child must literally work on himself twice as much as a non-Romani child...... there should be a mentor or someone who would show the teacher the different forms of teaching strategies to include the student so that he wouldn't feel different. When he comes to the classroom, smile at him. These are the little things that I really know play a big role for those Roma children. I know it myself, that I can be satisfied with just a smile and someone to trust me. And in some children, I see it too. Yeah, when he comes, he gives the teacher a high five. Yeah, a more informal relationship.'

In some non-segregated schools, the lack of will to create an inclusive school climate and to challenge prejudice among teachers and students could be a major obstacle, and sometimes this barrier seems to be too high to overcome immediately. Unfortunately, in some school districts, even the municipalities are not willing to support the transition of Roma students from segregated to mainstream schools, because they worry about the reaction of the majority students' parents.

In these cases, when reassignment of Roma students to non-segregated school is not possible straight away, there is a strong need to focus on segregated schools to increase the ability of these schools to attract nonRoma students, thereby facilitating their desegregation process. Particular examples of good practice here include efforts to make the school open to the parents and to the public, a greater focus on alternatives in educational programs, cooperation with out-of-school partners, improvement of the school's reputation and promotion of positive publicity about the school in the media.

\section{B. Making segregated schools more attractive to non-Roma students and their parents}

According to some school principals, one way to attract non-Roma parents to at least consider enrolling their child in a 'Roma school', is to be as open as possible, invite those parents to the school, let them experience the school atmosphere and observe some school lessons. Some parents still decide to put their child elsewhere, but others, when they see that the school provides a safe environment and an attractive educational program, enroll their child in this school.

Zuzana, deputy principal, Oak Tree Elementary School (60\% socially disadvantaged Roma students): 'When someone wants to put a child here, we do not disguise what school we are, on the contrary, we want parents to visit, even with their child. We guide them all around the school, they can attend a lesson. We arrange another 
meeting, so that they know from the beginning what they can expect... Then they enroll them, because, as I say, they like it very much and often they are pleasantly surprised how we teach here. Today, for example, we have a project day, and you can see that there is just the normal school activity...'

In some cases, preparatory courses organized by the school for preschool children can help. Both children and their parents have the opportunity to gain their first experience of the school environment and to test how suitable the school is for them - then decide whether to enroll the child in this school or elsewhere.

Michaela, principal, Chestnut Tree Elementary School (35\% socially disadvantaged Roma students): '....we let the parents of children who come to us speak: It happened to be my ex-classmate who said: "I went to the preparatory course, with doubts. My wife told me, come on, let's go try it. Okay, but I don't want to go there, it's Chestnut Elementary." Then he said: "Yeah good, it's just a preparatory course. So we'll just see." And then it was enrollment time, and they came and enrolled him here, and said: "I'm happy today, I do not mind the Roma at all, no conflicts anywhere, everything is fine, I'm glad that the boy is here."'

Another way to make the 'Roma school' more attractive to parents of majority children is to focus more on alternatives in their educational programs. This strategy may be particularly useful in medium-sized and large cities, where there is a larger population of liberal parents seeking less traditional forms of education for their children.

Pavel, an expert: '...and it seemed to me that the school principal had taken quite a good step, actually, when he opened a parallel class with the Step by Step program. And it seems to me that that's why other people went there, other than those with social disadvantages, because it attracts them. And these people are open, not racists, and that is why some kind of natural mixing of people happens there.'

These alternative educational strategies, which favor the freedom of the child in learning over traditional frontal teaching, often suit the needs of Roma students. At the same time, any such alternative can be an attractive offer for those non-Roma students for whom the traditional approaches of other schools would be too restrictive.

Romana, principal, Poplar Tree Elementary School (50\% socially disadvantaged Roma students): 'We are attracting them to what I would say was a tendency toward the alternative. Not to an extreme, but still. But we do not limit teaching outside, in the park; when children want to walk barefoot, they walk barefoot. We have community circles... I would say that there is a little mixing of some Waldorf pedagogy, we try to work a lot with illustrative examples, with aids, so that the teaching is neither boring, nor merely frontal.'

Another example of good practice in making schools more attractive to majority parents can be found in the area of improving cooperation with out-of-school partners. As mentioned by František, principal of the Fir Tree Elementary, many forms of systematic cooperation with local companies can help the school gain an advantage in competition with other schools. As a result, it may be this cooperation with out-of-school institutions that can get parents of non-Roma students to enroll their children in a particular school, even when it is attended by an above-average number of Roma students.

František, principal, Fir Tree Elementary School (17\% socially disadvantaged Roma students): '... I have a lot of friends who have succeeded in managerial positions in various interesting companies, and so on. So we went to the pub, we had such a nice project of mutual cooperation, with really important partners, [ the name of a bank company], [the name of an engineering company], [the name of a furniture maker], those really big employers and players in my city... And I didn't want money, I wanted a declared partnership. I told them, I want us to be seen working together, that you are demonstrating something to our children, teaching them something. So the director of the bank comes here to teach financial literacy in the third grade. This is just absolutely great, no one else here has anything like that. He brings a money counter, fake money, old money. And he comes and brings the branch director with him, and they work with the children like that. And that's wonderful. Or the director of [the name of a construction company] a big company that is building with huge investments. We are also former classmates, so we also made an arrangement with his company; we offered them some cultural performances by our students at corporate events, for example, and they in turn helped us, for example, to enter into a project where children build using kits and bricks, or they take our children to the zoo, pay for the bus for them, and so on. So that's how we do things together.' 
An important condition for getting the parents of non-Roma students to enroll their children in a previously segregated school is to improve the school's reputation. In this area, lots can be done inside the school, mainly in changing the teachers' attitudes and their presentation of the school in public. It seems that the teachers, when talking about their school outside of the school, often emphasize the challenging behavior of Roma students, and therefore the school is labelled as a "problem Roma school". Therefore, it is important to persuade school staff to promote better their school's reputation and to present the school's achievements even in informal communication with people from the neighborhood.

Iva, principal, Pine Tree Elementary School (17\% socially disadvantaged Roma students): '... But most of all, the people who work here must not spread what is not true. Because when these people say that they have Roma in their classes and that it's terrible, the people out there are going to latch onto it and start saying 'Jesus Christ, she teaches there and it's clear there are Roma there, and she teaches them and it's horrible. 'And then there is no longer a question of whether she has a problem with one child or with half the class. Everything is generalized; there is a problem there, I would not enroll a child there, and so on. So, first you have to work with the staff so that they learn not to talk about these things in such a way and they start seeing it all as it really is, which is difficult.'

Another powerful measure to make the school more attractive to non-Roma parents is promoting positive publicity about the school in the media. Experience shows that long-term and systematic building of the school's good reputation in both printed and electronic social media can significantly contribute to a positive perception of the school among majority parents, and thus media presentation promotes non-Roma parents' willingness to enroll their children in a school with an above-average number of Roma students.

František, principal, Fir Tree Elementary School (17\% socially disadvantaged Roma students): '... I made an arrangement with a journalist here, the town publishes a monthly magazine, so I started to write some articles about education in it. Not only about the school, who visited and whom we met, but generally about education: what parents expect from school today, what children are in education and what it entails. This is to make parents more aware of what school actually means, because everyone today feels that they understand education, because they went to school, but it is not so easy. And I did this all year. In fact, every month I found something here, when the data and statistics were collected, and I kind of wrote about little things and even about more professional things so that even grandma would understand. Which, I have to say, was quite appreciated, and I always put our school logo there ... But we also needed to address that group of people who don't read printed newspapers. Youth today and newspapers, they don't go together, do they. Especially the moms; they are thirty, they have children who are around three years old, and they are starting to plan for school. And they don't sit by the sandbox, they share on Facebook. So we have school websites and Facebook pages where every other day we share photos, activities, and some short, two-or-three-sentence, comment. We have a promotional team, two of our teacher assistants, they have some extra money for that, and they have the opportunity to consult with an expert, an internet publicist and marketer on social networks.'

\section{DISCUSSION AND CONCLUSION}

According to all the testimonies of the research participants, there seem to be two main areas of possible intervention in order to facilitate the desegregation of Roma schools. First, the educational system should support the transition of Roma students to non-segregated mainstream schools.

One of the possible interventions could be the closure of a segregated school, which would force the Roma students to start to attend another school. However, the success of this intervention often seems to be limited. Lauritzen and Nodeland (2018) warn about the risk of 'white-flight', the withdrawal of non-Roma students from schools in which are Roma students are newly included. Logan, Minca and Adar (2012) show that even after the closure of a segregated school, overrepresentation of socially disadvantaged ethnic minority students may still be the reality in other schools in the region. Čada and Hůle (2019) show, in an example of good practice, that the abolition of a segregated school can be a solution, but only if it is accompanied by long-term effective cooperation between the municipality and school principals willing to manage an even distribution of socially disadvantaged Roma students among the elementary schools in the region.

Another measure to promote the attendance of Roma students in mainstream schools could be 'bussing' - the establishment of school buses that import Roma students into non-segregated schools. Although there are examples of good practice, such as the case in Vidin in Bulgaria described by Ryder, Rostas and Taba (2014), 
there are some limitations to this strategy as well. As recognized by the Public Defender of Rights (2018, some school principals argue against bussing, emphasizing that the best school for every child should be the closest and that commuting to some more distant school could increase the absence rate of students.

The key role in the transfer of Roma students to mainstream schools is played by municipalities, which set the catchment areas of schools and can thus systematically influence the numbers of socially disadvantaged Roma students in particular schools. In this regard, Čada and Hůle (2019) emphasize that socially disadvantaged Roma families often migrate within the city and that the catchment areas of schools should therefore be changed on an ongoing basis. Higher involvement of Roma parents can also represent another vital dynamic in the process of desegregation: Although Želinský, Gorard and Siddiqui (2021) confirmed that - in comparison to non-Roma many Roma parents express lower levels of educational aspirations for their children, a recent study by Moree (2019) shows that Roma parents are increasingly aware of the education system and that they want either to send their children to a mainstream school or have them in a segregated school, but one with a high quality of education. Walker (2008) also emphasizes that in order to overcome discrimination in education, ethnic minorities should set high expectations for themselves.

Another important area of intervention to aid the inclusion of Roma students in mainstream schools is represented by activities aimed at changing the overall atmosphere in these schools. As pointed out by Thijs and Verkuyten (2014), the creation of an ethnically mixed school environment can increase ethnic tensions, therefore working on the school climate and implementing new strategies for multicultural education seem essential. This could be a key issue in the Czech Republic - according to research published by Cichá et al. (2016), more than half of Czech primary and secondary school teachers noted that their students' attitude towards Roma students was negative; Svoboda and Zilcher (2019) in their research also showed that students of Czech and Slovakian elementary schools are less willing to provide any above-standard measures, if these measures should support the education of socially disadvantaged Roma students. The perspective of the Roma themselves has been expressed in a study by Amnesty International (2015), in which Roma children described extensive experience of bullying by non-Roma classmates and sometimes even by teachers. According to Zachos (2017), the opinions and attitudes of teachers themselves towards the Roma should be an important part of the development of the school atmosphere; in the Czech context, this is shown by the research of Jarkovská, Lišková and Obrovská (2015), according to which many teachers justify their attitudes by imaginary barriers arising as a result of 'insurmountable' cultural differences of Roma students.

Second, in areas where it is not possible to transfer Roma students to non-segregated educational settings, the segregated schools should do their best to become more attractive for non-Roma students and their parents. The communication and openness of the school represent powerful instruments here - as emphasized by the Public Defender of Rights (2018). For successful desegregation it is necessary to talk to both Roma and nonRoma parents, to let them meet each other and to assure them that the best interest of their children is the primary aim of the school. In this respect, a controversial response may be triggered by the strategy observed by Amnesty International (2015), a strategy in which schools try to improve their reputation by making Roma students 'less visible', for example, by postponing the start of the preparatory class, which is mainly attended by Roma students, in an effort to prevent the meeting of Roma and non-Roma parents in the school area during the morning hours; on the one hand, this is likely to help the school to avoid being classified as a 'Roma school', but, on the other hand, this kind of strategy certainly does not contribute to reducing tensions between Roma and non-Roma. And, in a number of other cases, such an attempt to make Roma students 'less visible' may in fact lead to the mere replacement of one segregation mechanism by another.

Whereas primary schools in the Czech Republic are largely left to market principles - parents choose the school they consider best for their child - promoting the offer of alternative educational programs may also be an effective way to desegregate 'Roma schools'. The Public Defender of Rights (2018) suggests that segregated schools should try to attract non-Roma students and their parents by introducing educational specializations, which are demanded by parents and not covered by other schools in the area; e.g. classes with extended teaching of ICT, languages, sports, music or arts, or classes with alternatives such as Montessori or Waldorf education.

Positive presentation of the school in local media and on social networks can also significantly increase the interest of non-Roma students and therefore support the overall process of desegregation. In the past, Mušinka (2012) described a positive example in this area at a primary school in Spišský Hrhov in Slovakia - a 
school where approximately half the students are Roma, which, thanks to intensive cooperation with the print media and local television, managed to achieve the status of a popular and attractive school.

In addition to changes leading to the transition of Roma students to mainstream schools and measures to encourage the entry of non-Roma students into segregated schools, there seems to be one further important need - the need to change the whole discourse, to shift from a narrow 'Roma- specific' focus on desegregation, to a wider conception of creating inclusion for all learners. As mentioned by one expert involved in the research:

Petra, an expert: 'It's the same thing when you're advertising. If you want someone to be interested in the ad, it must sound appealing. So it is with communicating the issue. Not to communicate it as a problem, but to change the narrative of it. Communicate it like something beneficial. Not to say, here is desegregation or whatever. But to say, we just want to improve our school, we want to make it better in this city. Just find a positive narrative.'

The need of this shift is also confirmed by research findings showing that even for other ethnic minorities or other vulnerable groups, the positively intended form of segregation may outweigh the negative consequences (Fandrem et al., 2021; Nusbaum, 2013).

Partly, it is also an issue of naming - the research by The Public Defender of Rights (2018) shows that elementary school principals themselves avoid using the term 'desegregation', probably because they are aware of the negative connotations that the public associates with this term. At the same time, it is a question of the overall focus of the planned interventions, which should be less 'ethnically specific' and more oriented towards all 'in need'; such interventions would be in line with the findings of Kostka (2015), who compared the effectiveness of SF financed projects and concluded that an ethnically neutral approach is much more effective than ethnicization of the issue. A shift from desegregation, narrowly aimed at promoting the education of socially disadvantaged Roma students, to a broader concept of the development of inclusive education for all, could also increase the necessary public support for the suggested interventions. And, as Rostas (2012) emphasized, in efforts to desegregate, the Roma remain alone, while in efforts to create an inclusive learning environment for all, the interests of the Roma are linked to the interests of disabled students and other disadvantaged groups. And it is obvious that collectively claimed interests of disadvantaged minorities have a greater chance of support and a greater chance of success.

In sum, desegregation itself is an achievable objective, but it requires the cooperation of all actors, municipalities and NGOs, segregated and non-segregated schools, Roma and non-Roma parents and students. And of course, it also requires the will to change, the will to build a truly equal society without any discrimination or segregation at all.

\section{References}

[1] Amnesty International. (2015). "Chce to více snahy: Etnická diskriminace romských dětí v českých školách" [It takes more effort: Ethnic discrimination of Roma children in Czech schools]. London: Amnesty International. $\quad$ https://www.amnesty.cz/data/file/1993-chce-to-vice-snahy vyzkumnazprava.pdf?version $=1457287650$

[2] Arabadjieva K. (2016). "Challenging the school segregation of Roma children in Central and Eastern Europe". International Journal of Human Rights 20: 33-54. doi: 1013642987.2015.1032266.1080/

[3] Araújo, M. (2016) A very 'prudent integration': white flight, school segregation and the depoliticization of (anti-)racism, Race Ethnicity and Education, 19: 300-323, doi:10.1080/13613324.2014.969225

[4] Cashman, L. (2017) New label no progress: institutional racism and the persistent segregation of Romani students in the Czech Republic. Race Ethnicity and Education, 20: 595-608, doi:10.1080/13613324.2016.1191698 
[5] Cichá, M., J. Maláčová, B. Moravcová, A. Preissová Krejčí, M. Prokeš and M. Roubínková. (2016). “Romové očima pedagogů základních a středních škol" [Roma from the perspective of primary and secondary school teachers]. 21-30. http://www.antropoweb.cz/webzin/index.php/webzin/article/view/224

[6] Committee of Ministers, Council of Europe (2019). Communication from the authorities ("Comprehensive Evaluation of the Reform of Inclusive Education in Relation to Roma Pupils") (05/04/2019) in the case of D.H. AND OTHERS v. Czech Republic (Application No. 57325/00). Retrieved from:: https://www.coe.int/en/web/portal

[7] Council of Europe. (2017). Fighting school segregation in Europe through inclusive education: a position paper. Council of Europe, Commissioner for Human Rights. https://rm.coe.int/fighting-schoolsegregationin-europe-throughinclusive-education-a-posi/168073fb65

[8] Čada, K., and D. Hůle, D. (2019). Analýza segregace v základních školách z pohledu sociálního vyloučení [Analysis of segregation in elementary schools from the perspective of social exclusion]. Prague: Office of the Government of the Czech Republic, Department for Social Inclusion (Agency). https://www.socialnizaclenovani.cz/wp-content/uploads/Analyza segregace 2019 1.1.pdf

[9] European Roma Rights Centre. (2004). Stigmata: Segregated Schooling of Roma in Central and Eastern Europe. Budapest: European Roma Rights Centre. http://www.errc.org/reports-andsubmissions/stigmata-segregated-schooling-of-roma-in-central-and-eastern-europe

[10] European Union Fundamental Rights Agency. (2017). Second European Union Minorities and Discrimination Survey (EU-MIDIS II) Roma - Selected findings. Luxembourg: Publications Office of the European Union. doi:10.2811/469

[11] Fandrem, H., Jahnsen, H., Nergaard S.E. \& K. Tveitereid (2021) Inclusion of immigrant students in schools: the role of introductory classes and other segregated efforts. International Journal of Inclusive Education. doi:10.1080/13603116.2021.1950222

[12] Harry, B. (2007). "The disproportionate placement of ethnic minorities in special education." In The SAGE Handbook of Special Education edited by Lani Florian, 67 - 84 . London: SAGE. doi:10.4135/9781848607989.n7

[13] Hendl, J. (2008). Kvalitativní výzkum: základní teorie, metody a aplikace [Qualitative research: basic theories, methods and applications]. 2nd., updated edition. Prague: Portál.

[14] Jarkovská, L., Lišková, K. \& J. Obrovská (2015) 'We treat them all the same, but...'. Disappearing ethnic homogeneity in Czech classrooms and teachers' responses, Race Ethnicity and Education, 18: 632654, doi:10.1080/13613324.2015.1013457

[15] Kostka, J. (2015). "Implementation of Roma Inclusion Policies: Why Defining the Problem Matters." Social Inclusion 3: 78-89. doi:10.17645/si.v3i5.231.

[16] Lauritzen, S. and T. Nodeland (2018). "“What is the problem represented to be?" Two decades of research on Roma and education in Europe." Educational Research Review 24: 148-169. doi:10.1016/i.edurev.2018.04.002.

[17] Logan, J. R., E. Minca and S. Adar (2012). "The Geography of Inequality: Why Separate Means Unequal in American Public Schools." Sociology of Education 85: 287-301. doi:10.1177/0038040711431588.

[18] Messing, V. (2017). "Differentiation in the Making: Consequences of School Segregation of Roma in the Czech Republic, Hungary and Slovakia." European Education 49: 89 - 103. doi:10.1080/10564934.2017.1280336

[19] MEYS: The Ministry of Education, Youth and Sports, Czech Republic. (2017). Zpráva ke zjištování kvalifikovaných odhadů počtu romských žáků v základních školách ve školním roce 2016/2017 [Report on 
the investigation of qualified estimates of the number of Roma pupils in elementary schools in the school year 2016/2017]. Prague: MEYS Czech Republic. http://www.msmt.cz/file/39658/

[20] Moree, D. (2019). Cesty romských žáků ke vzdělávání. Dopady inkluzivní reformy [Pathways of Roma pupils to education. Impacts of inclusive reform]. Prague: Nadace Open Society Fund Praha.

[21] Mušinka, A. (2012). Podarilo sa - Príklady úspešných aktivít na úrovni samospráv smerujúcich k zlepšeniu situácie Rómov [We have succeeded in - Examples of successful activities at the level of self-governments aimed at improving the situation of the Roma]. Prešov: Prešovská univerzita v Prešove, 2012. http://archiv.vlada.gov.sk/romovia/data/files/8857.pdf

[22] Němec, Z. (2020). ,Zvedněte ruce, kdo půjde do mist, kde necítí uznání: O segregaci romských žáků ve vzdělávání ['Raise your hands who will go to places where they do not feel recognized': On the segregation of Roma students in education]. Praha: Univerzita Karlova, Pedagogická fakulta.

[23] Nusbaum, E.A. (2013) Vulnerable to exclusion: the place for segregated education within conceptions of inclusion, International Journal of Inclusive Education, 17: 1295-1311, doi:10.1080/13603116.2013.826292

[24] Public Defender of Rights (2018). Doporučení veřejné ochránkyně práv ke společnému vzdělávání romských a neromských dětí [Recommendation of the Public Defender of Rights for the Inclusive Education of Roma and Non-Roma Children]. Brno: Office of the Public Defender of Rights. File number: 86/2017/DIS/VB. $\quad$ https://www.ochrance.cz/aktualne/tiskove-zpravy-2018/cesta-ke-spolecnemuvzdelavani-romskych-a-neromskych-deti/

[25] Rostas, I. (2012). Ten Years After: A History of Roma School Desegregation in Central and Eastern Europe. New York: Central European University Press.

[26] Rostas, I. and J. Kostka (2014). Structural Dimensions of Roma School Desegregation Policies in Central and Eastern Europe. European Educational Research Journal, 13: 268-281. doi:10.2304/eerj.2014.13.3.268

[27] Ryder, A. R., I. Rostas and M. Taba (2014). "Nothing about Us without Us": The Role of Inclusive Community Development in School Desegregation for Roma Communities. Race, Ethnicity and Education 17: 518-539. doi:10.1080/13613324.2014.885426

[28] Strauss, A.L., Corbin, J. (1999) Základy kvalitativního výzkumu: postupy a techniky metody zakotvené teorie [Basics of Qualitative Research: Techniques and Procedures for Developing Grounded Theory]. Brno: Sdružení Podané ruce.

[29] Svoboda, Z., Zilcher, L. (2019) SOCIAL DISADVANTAGE AND THE POSSIBILITIES OF OVERCOMING IT PERCEIVED BY BASIC SCHOOL PUPILS IN THE CZECH AND THE SLOVAK REPUBLIC, ICERI2019 Proceedings, pp. 6220-6225.

[30] Thijs, J. and M. Verkuyten (2014). School ethnic diversity and students' interethnic relations. British Journal of Educational Psychology 84: 1-21. doi:10.1111/bjep.12032.

[31] Walker, G. (2008) 'Overrepresented Minorities in Special Education in the United States and Romania: Comparison between African-American and Roma Populations in Disability Studies'. Research in Comparative and International Education, 3: 394-403. doi:10.2304/rcie.2008.3.4.394

[32] Zachos, D.T. (2017) Teachers' perceptions, attitudes and feelings towards pupils of Roma origin, International Journal of Inclusive Education, 21: 1011-1027, doi:10.1080/13603116.2017.1326176

[33] Želinský, T., Gorard, S. \& N. Siddiqui (2021) Increasing understanding of the aspirations and expectations of Roma students, British Journal of Sociology of Education, 42: 588606, doi:10.1080/01425692.2021.1872366 